\title{
Parasites of cephalopods in the northern Tyrrhenian Sea (western Mediterranean): new host records and host specificity*
}

\author{
CAMINO GESTAL ${ }^{1}$, PAOLA BELCARI ${ }^{2}$, ELVIRA ABOLLO ${ }^{1}$ and SANTIAGO PASCUAL ${ }^{1}$ \\ ${ }^{1}$ Laboratorio de Parasitología, Facultad de Ciencias del Mar, Universidad de Vigo. Ap.874-36200 Vigo. Spain. \\ ${ }^{2}$ Dipartimento di Scienze dell’Uomo e dell’Ambiente. Universitá degli Studi di Pisa. Vía Volta 6, 56126 Pisa, Italy.
}

\begin{abstract}
SUMMARY: This paper examines the species composition of the parasite fauna and the values of infection for seven species of cephalopods in the Mediterranean at the Tyrrhenian Sea (West coast of Italy). Results suggest the important role of cephalopods as intermediate hosts in the life cycle of anisakine nematodes and pennellid copepods. The low host specificity (i. e., eurixenous condition) of metazoan parasites in cephalopods worldwide is also reinforced.
\end{abstract}

Key words: Cephalopod molluscs, parasite fauna, Tyrrhenian Sea.

\section{INTRODUCTION}

Cephalopods are fast-growing predatory molluscs which play a vital role in the food webs of marine ecosystems (Amaratunga, 1986). Historically, cephalopods have been actively exploited in the western Mediterranean. Within the Mediterranean the areas yielding the highest percentage of cephalopods with respect to total demersal catches are the Tyrrhenian and Ligurian Seas (Belcari and Sartor, 1993). Despite an increasing commercial significance and the importance of cephalopods in the trophic ecology and fisheries in this area, our knowledge of the role of cephalopods as hosts for parasites is fractionary and incomplete (Hochberg, 1990). Previous studies have indicated that cephalopods are susceptible to infection by a number of parasite groups in the Mediterranean Sea (Dollfus, 1958; for

\footnotetext{
*Received February 18, 1998. Accepted November 18, 1998.
}

review in Hochberg, 1990). However, no data on the host-parasite relationship has been published for this region. This paper, which is complementary to a larger study on the role of cephalopods as hosts for parasites in European waters, (Pascual et al. In progress), analyzes the parasite fauna of seven species of cephalopods in the Tyrrhenian Sea adjacent to the Tuscany region off the west coast of Italy.

\section{MATERIAL AND METHODS}

Samples were gathered in the northern Tyrrhenian Sea during a trawl survey carried out in October and November 1996, during the research programe "Valutazione delle risorse demersali" financied by the Italian Ministero Politiche Agricole. Fig. 1 shows the study area and the allocation of the hauls related to the present study. Details of sampling, materials and methodology used are found in Table 


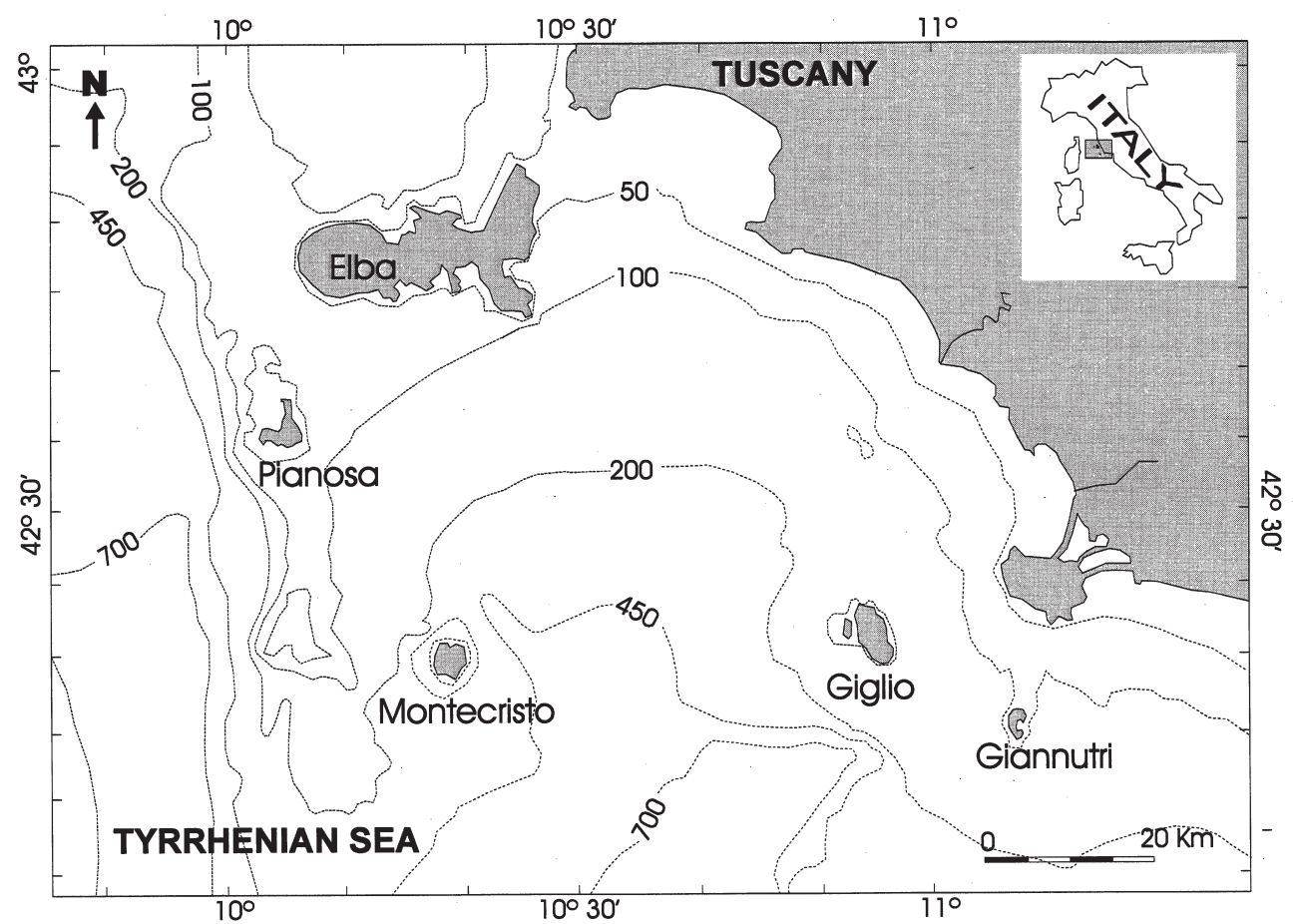

FIG. 1. - Study area and sample stations.

TABLE 1. - Host data: haul number; locality (latitude North "N" + longitude East "E"), n (number of individuals examined), ML (mantle length, range in millimeters), BW (total body weight, range in grams) and percentage of maturity stages ( (I), immature; (II), maturing; (III), mature). Allotheuthis sp. refers to specimens damaged by fishery operations and not identifiable as either A. media or A. subulata.

\begin{tabular}{|c|c|c|c|c|c|c|c|}
\hline Host & haul & locality & depth (m) & $\mathrm{n}$ & ML (mm.) & BW (g.) & Mat. (\%) \\
\hline \multicolumn{8}{|l|}{ Sepioidea } \\
\hline Rhombosepia elegans & $\mathrm{B}$ & $42^{\circ} 46^{\prime} \mathrm{N}, 10^{\circ} 39^{\prime} \mathrm{E}$ & 71 & 35 & $17-59$ & $2-15$ & $\begin{array}{l}22.9 \text { (I) } \\
40 \text { (II) }\end{array}$ \\
\hline Rhombosepia orbignyana & A & $42^{\circ} 41^{\prime} \mathrm{N}, 10^{\circ} 23^{\prime} \mathrm{E}$ & 99 & 25 & $25-75$ & $3-16$ & $\begin{array}{c}37.1 \text { (III) } \\
84 \text { (I) } \\
16 \text { (III) }\end{array}$ \\
\hline $\begin{array}{l}\text { Teuthoidea } \\
\text { Loligo vulgaris }\end{array}$ & $\mathrm{D}$ & $42^{\circ} 39^{\prime} \mathrm{N}, 10^{\circ} 58^{\prime} \mathrm{E}$ & 13 & 65 & $32-151$ & $2-89$ & $95.4(\mathrm{I})$ \\
\hline \multirow[t]{2}{*}{ Alloteuthis subulata } & $\mathrm{D}$ & $42^{\circ} 39^{\prime} \mathrm{N}, 10^{\circ} 58^{\prime} \mathrm{E}$ & 13 & 14 & $37-52$ & $2.3-4.1$ & $\begin{array}{c}4.6 \text { (II) } \\
78.5 \text { (I) } \\
1.4 \text { (II) } \\
7.1 \text { (III) }\end{array}$ \\
\hline & $\mathrm{E}$ & $42^{\circ} 43^{\prime} \mathrm{N}, 10^{\circ} 54^{\prime} \mathrm{E}$ & 30 & 9 & $35-57$ & $1.8-4.8$ & $\begin{array}{l}11.1 \text { (I) } \\
55.5 \text { (II) }\end{array}$ \\
\hline \multirow[t]{2}{*}{ Alloteuthis media } & $\mathrm{D}$ & $42^{\circ} 39^{\prime} \mathrm{N}, 10^{\circ} 58^{\prime} \mathrm{E}$ & 13 & 14 & $51-70$ & $4.4-9.5$ & 57.1 (I) \\
\hline & $\mathrm{E}$ & $42^{\circ} 43^{\prime} \mathrm{N}, 10^{\circ} 54^{\prime} \mathrm{E}$ & 30 & 23 & $35-66$ & $2.4-6.6$ & $\begin{array}{l}26 \text { (I) } \\
34.7 \text { (II) } \\
34.7 \text { (III) }\end{array}$ \\
\hline \multirow[t]{2}{*}{ Alloteuthis sp. } & $\mathrm{D}$ & $42^{\circ} 39^{\prime} \mathrm{N}, 10^{\circ} 58^{\prime} \mathrm{E}$ & 13 & 31 & $32-67$ & $1.3-10.1$ & $\begin{array}{l}80.6 \text { (I) } \\
9.7 \text { (II) } \\
9.7 \text { (III) }\end{array}$ \\
\hline & $\mathrm{E}$ & $42^{\circ} 43^{\prime} \mathrm{N}, 10^{\circ} 54^{\prime} \mathrm{E}$ & 30 & 10 & $40-69$ & $1.9-6$ & $\begin{array}{l}20 \text { (I) } \\
40 \text { (II) } \\
40 \text { (III) }\end{array}$ \\
\hline Illex coindetii & $\mathrm{C}$ & $42^{\circ} 27^{\prime} \mathrm{N}, 10^{\circ} 26^{\prime} \mathrm{E}$ & 133 & 42 & $50-148$ & $4-72$ & $\begin{array}{l}88 \text { (I) } \\
2.3 \text { (II) } \\
9.5 \text { (III) }\end{array}$ \\
\hline $\begin{array}{l}\text { Octopoda } \\
\text { Eledone cirrhosa }\end{array}$ & A & $42^{\circ} 41^{\prime} \mathrm{N}, 10^{\circ} 23^{\prime} \mathrm{E}$ & 99 & 25 & $41-65$ & $30-97$ & 100 (I) \\
\hline
\end{tabular}

40 C. GESTAL et al. 
TABLE 2. - Parasites recorded in cephalopods at the Tyrrhenian Sea. (Site, site of infection; P, prevalence; I, mean intensity; **parasites found in the haul E; + new host record).

\begin{tabular}{|c|c|c|c|c|}
\hline Host & Parasite & Site & $\mathrm{P}(\%)$ & I \\
\hline \multicolumn{5}{|l|}{ Sepioidea } \\
\hline $\begin{array}{l}\text { Sepia elegans } \\
\text { Sepia orbionvana }\end{array}$ & - & - & - & - \\
\hline \multirow{2}{*}{\multicolumn{5}{|c|}{ Teuthoidea }} \\
\hline & & & & \\
\hline Illex coindetii & $\begin{array}{l}\text { Anisakis simplex } \\
\text { Pennella sp. }+\end{array}$ & mantle cavity & $\begin{array}{l}4.8 \\
100\end{array}$ & 1 \\
\hline Loligo vulgaris & Pennella sp. & gills & 1.5 & 2 \\
\hline & Anilocra physodes + & mantle cavity & 3 & 2 \\
\hline Loligo vulgaris & Pennella sp. & gills & 1.5 & 2 \\
\hline Alloteuthis subulata & - & - & - & - \\
\hline Alloteuthis media & **Pennella $\mathrm{sp} .+$ & gills & 4.3 & 1 \\
\hline Alloteuthis sp. & $x$ & 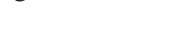 & & \\
\hline Octopoda & 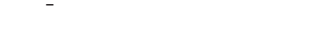 & - & - & - \\
\hline Eledone cirrhosa & $\begin{array}{l}\text { Hysterothylacium sp.+ } \\
\text { Pennella sp. }+\end{array}$ & $\begin{array}{l}\text { digestive tract } \\
\text { gills }\end{array}$ & $\begin{array}{c}28 \\
4\end{array}$ & $\begin{array}{r}2.1 \\
1\end{array}$ \\
\hline
\end{tabular}

1 as previously described in Belcari and Sartor (1993). A total of 303 post-recruit cephalopods of both sexes belonging to seven species were collected. Upon collection, animals were fixed (formalin $10 \%$ ) and preserved (ethanol 70\%). Specimens were measured (ML, mantle length), weighed (BW, total body weight), sexed, and assigned to a maturity stage based on the appearence and relative sizes of the gonads. Three maturity stages were considered: immature, maturing and mature (stage I, II, III, respectively). Table 1 summarizes the provenence and characteristics of the specimens studied. Following necropsy under a stereomicroscope, fixed specimens were examined for protozoan and metazoan parasites using standard diagnostic techniques. Ecological terms referred in the text, namely; prevalence $(\mathrm{P})$ and mean intensity (I) of infection, follow the definition of Margolis et al. (1982) and Bush et al., (1997).

\section{RESULTS}

Parasitological examination revealed that of the seven species of cephalopod studied, four harboured metazoan parasites namely: Nematodes (Anisakidae); Copepods (Pennellidae); and Isopods (Cymothoidae). The remaining host species were not parasitized (Table 2). Protozoan parasites were not detected.

\section{Nematodes:}

Ascaridoids identified members of the genus Hysterothylacium (Ward and Magath, 1917) consti- tutes a new parasite record for the lesser octopus, Eledone cirrhosa (Lamarck, 1798), and extend the host range of this parasite to the Mediterranean Sea. Prevalence of anisakines (both the Anisakis simplex complex and Hysterothylacium sp.) ranged from 4.8 to $28 \%$ (mean intensity from 1 to 2.1 ).

\section{Crustaceans:}

Copepods of the genus Pennella (Oken, 1816) were recorded for the first time on the gills of the mid-sized squid Alloteuthis media (Linnaeus, 1758), the broadtail shortfin squid Illex coindetii (Verany, 1839), and the lesser octopus E. cirrhosa at the Mediterranean Sea. The prevalence of Pennella ranged from 1.5 to $100 \%$ (mean intensity from 1 to 2).

Isopods:

The mantle cavity of two european squids Loligo vulgaris (Lamarck, 1798) were parasitized by a cymothoid isopod, Anilocra physodes, constituing a new host record for this parasite, and the third case of a cymothoid reported from a cephalopod in the Mediterranean Sea.

Of the cephalopods examined the gills were the most important site of infection (76.4\% of all parasitized hosts); the digestive tract was parasitized by nematodes in 6 host individuals $(10.9 \%)$, and the mantle cavity of 4 host individuals (7.2\%), was parasitized by nematodes and isopods.

The study of the relative species diversity (average number of species of each parasite group per total host records) showed values ranging from 0.25 for nematodes to 0.5 for crustaceans. 


\section{DISCUSSION}

In a recent paper on host range and biogeography of cephalopod parasites Pascual et al. (1996) indicated that protozoans (eimeriorin coccidians of Aggregatidae and dicyemid mesozoans) and crustacean parasites were the most important parasitic groups recorded in the Mediterranean Sea. In agreement with this work, the values of infestation reported in this paper demonstrated that cephalopods are very important intermediate hosts for crustaceans, as has also been noted in a work related to the southeastern north Atlantic waters (Pascual et al., in prep.). Dicyemid mesozoans have been reported in temperate waters. In that area, practically all the cephalopod species have a prevalence of $100 \%$ (Hochberg, 1990). Because parasitological examination was carried out on fixed specimens, no attempt was made to determine the specific presence of dicyemids in the renal appendages, thus the absence of this parasitic group in our study. It can be argued that if the specimens had been fresh, and if all parasites have been recorded than perhaps the renal appendages would be the most important site of infection.

Dobell (1925) elucidated the presence of coccidians of the genus Aggregata (Frenzel, 1885) in the Mediterranean at Naples. He indicated that sexual stages which occur in the digestive tract of cephalopods, only infect benthic cephalopods of the species Sepia officinalis (Linnaeus, 1758) and Octopus vulgaris (Cuvier, 1797). The absence of Aggregata in the seven species of cephalopods examined in the present study supports the concept of a high degree of host-specificity of those coccidians in cephalopods, as has been suggested by Hochberg (1990).

Even thougth Pennella was identified as Pennella varians (Rose \& Hamon, 1953) in a great variety of cephalopods in the Mediterranean Sea (Wierzejs$\mathrm{ki}, 1877)$, the larval condition of this parasite made its specific identification not possible.

Cymothoids are isopod crustaceans which typically infest fishes, both Osteichyes and Chondrichthydes. Anilocra physodes has been recorded from the skin of fishes such as Boops boops (Linné, 1758), Diplodus annularis (Linné, 1758), Paganellus piscatorius (Linné, 1758) and Sardina pilchardus (Walbaum, 1792) (Bello and Mariniello in press.). Cephalopods occasionally have been reported to host cymothoids (Hochberg, 1990) in the Pacific and Atlantic oceans. The only Mediterranean records until now were Meinertia sp. on the neck of Sepia elegans (Blainrille, 1827) (Dollfus, 1958) and Livoneca sinuata (Koebel, 1878) in Sepiola ligulata (Naef, 1912) (Bello and Mariniello in press). Despite the above authors have described the isopod as a parasitic form, it is not unlike that they could be accidentally acquired when they both occur in trawl nets and are drawn into the mantle cavity during respiratory intake of water by the squid.

Pascual et al. (revising published papers) calculated that the relative species diversity of cephalopod parasites in the Mediterranean Sea was $0.5 \pm$ 0.2. In the northern Tyrrhenian Sea we found the same value. The relative species diversity for both nematodes and crustaceans in our sampling area was 0.35 . The values ranged from 0.25 for nematodes to 0.5 for crustaceans. When comparing our results to those from NW Spanish waters, patterns of species composition of the parasite fauna, site of infection and the demographic parasitic values (P and I) in the different host species appear to be very similar, even taking into account the immature status of most of the cephalopods examined for parasites in our sampling. This further confirms that metazoans have a wide host distribution (i.e eurixeneous) in cephalopods, as was previously suggested by Gaevskaya and Nigmatullin (1978).

\section{ACKNOWLEDGMENTS}

The authors wishe to thank Dr. L. Mariniello (Istituto di Parassitologia, Università "La Sapienza", Roma, Italy) for her helpful comments for the isopod identification. This work was supported by the Italian Ministerio Politiche Agricole and the Spanish Xunta de Galicia under the project (XUGA 30110A97).

\section{REFERENCES}

Amaratunga, T. - 1986. The role of cephalopods in the marine ecosystems. In: FAO Fisheries Technical Report, 231: 397415 .

Belcari, P. and P. Sartor. - 1993. Bottom trawling teuthofauna of the northern Tyrrhenian Sea. Sci. Mar., 57 (2-3): 145-152.

Bello, G. and L. Mariniello. - (in press). Occurence of Livoneca sinuata (Isopoda:Cymothoidae) in the mantle cavity of Sepiola ligulata (Cephalopoda: Sepiolidae).

Bush, A.O., K.D. Lafferty, J.M. Lotz and A.W. Shostak. - 1997. Parasitology meets ecology on its own terms: Margolis et al. revisited. J. Parasitol., 83 (4): 575-583.

Dobell, C.C. - 1925. The life history and chromosome cycle of Aggregata eberthi. Parasitol., 17:1-139.

Dollfus, R.P. - 1958. Copèpodes, isopodes et helminthes parasites de céphalopodes de la Méditerranée et de l'Atlantique 
européen. In: Faune marine de Pyrénées orientales, 2: 61-72.

Gaevkaya, A.V. and Ch.M. Nigmatullin. - 1978. The helminthfauna of Atlantic squids of the family Ommastrephidae (Cephalopoda: Oegopsida). Malacol. Rev., 11: 134-135.

Hochberg, F.G. - 1990. Diseases of Mollusca: Cephalopoda. In: Kinne, O. (ed.) Diseases of Marine Animals. Vol. III. Cephalopoda to Urochordata. pp 47-227, Biologisches Anstalt Helgoland, Hamburg.

Margolis, L., G.W. Esch, J.C. Holmes, A.M. Kuris and G.A. Schad. -1982 . The use of ecological terms in parasitology. J. Parasitol., 68 (1): 131-133.
Pascual, S., C., Gestal, J.M. Estévez, H. Rodriguez, M. Soto, E. Abollo, and C. Arias. - 1996. Parasites in commerciallyexploited cephalopods (Mollusca, Cephalopoda) in Spain: an updated perspective. Aquaculture, 142: 1-10.

Wierzejski, A. - 1877. Ueber Schmarotzerkrebse von Cephalopoden. Z. Wiss. Zool., 29: 562-582.

Scient. ed.: C. Pedrós-Alió 